\title{
NUMERIKUS SZÁMÍTÁSOK HATÉKONYSÁGÁNAK VIZSGÁLATA PYTHON, MATLAB ÉS OCTAVE PROGRAMCSOMAGOKKAL
}

\author{
Gyulai Márk \\ programtervezö informatikus hallgató, Miskolci Egyetem, Informatikai Intézet \\ 3515 Miskolc, Miskolc-Egyetemváros
}

\begin{abstract}
Absztrakt
A numerikus analizis a matematikai problémák közelitó, számitógéppel is hatékonyan elvégezhetö megoldásával foglalkozik. A cikkben bemutatott kutatás célja, hogy összehasonlítja a Python NumPyés SciPy, a Matlab és GNU Octave programcsomagok alapvetö numerikus algoritmusainak sebességét. A bemutatásra kerülö sebességtesztek olyan alapvetö numerikus müveletekre koncentrálnak, mint a mátrix müveletek, interpolációk, lineáris egyenletrendszer megoldása, valamint a numerikus integrálás és deriválás. Különbözö méretü tesztfeladatok esetén, az egyes müveletek elvégzéséhez szükséges idöket fogjuk összevetni, valamint a mérés során figyelembe vesszük az egyes implementációk közötti különbségeket is.
\end{abstract}

Kulcsszavak: Python, Matlab, Octave, numerikus analizis, mátrix müveletek, numerikus integrálás és deriválás, sajátérték, sajátvektor

\begin{abstract}
Numerical analysis deals with the approximate solution of mathematical problems that can be performed efficiently with computers. The goal of this article is that, to find out, which programming tool is the fastest in various numerical problems. The software tools that I test are the Python with NumPy and SciPy packages, the Matlab and the GNU Octave. Our tests are focusing at the basic numerical operations, like matrix operations, interpolations or solving linear equation systems or compute derivates and integrates and trying to find out which tool is the fastest in the given test and which is the fastest overall.
\end{abstract}

Keywords: Python, Matlab, Octave, numerical Analysis, matrix operations, numerical integration and derivation, eigenvalue, eigenvector

\section{Bevezetés}

A cikk témája különböző széles körben használt matematikai eszközök hatékonyságának vizsgálata alapvető numerikus számítások elvégzése esetén. Ilyen numerikus problémák, például a mátrix transzponálás, mátrix felbontások (LU, Cholesky), lineáris egyenletrendszerek megoldása, interpolációk vagy a numerikus deriválás és integrálás. A numerikus eljárások mindig az egzakt megoldást, vagy annak egy közelítését fogják adni. Numerikus számításokhoz sokféle szoftvert fejlesztettek ki, jelen cikkben 3 technológiára fogunk koncentrálni a Matlab, a Python és a GNU Octave programcsomagokra. Az utóbbi két rendszer nyílt forráskódú, ingyenesen elérhető. Más szerzők [11] is foglalkoztak hasonló összehasonlításokkal dinamikus rendszerek esetén. Cikkemben arra a kérdésre keresem a választ, hogy van-e lényeges különbség teljesítményben ezen széles körben használt alkalmazások teljesítményei között. 


\subsection{Numerikus számításokhoz használható programesomagokról és nyelvekről röviden}

\subsubsection{Fortran}

Az IBM által 1950-ben fejlesztett Fortran egy általános célú programozási nyelv, melyet napjainkban is használnak és fejlesztik is. Több programozási paradigmát is támogat, köztük az objektum orientáltságot, a procedurális és a generikus programozást is.

\subsubsection{Maple}

A Maple a Maplesoft által fejlesztett matematikai szoftvercsomag, mely egy hatékony matematikai motort kombinál egy könnyen használható felhasználói felülettel, ezáltal a használata egyszerủ és gyors. A felhasználói felület mellett parancssoros módban is képes müködni, a saját nyelvét használva, melyhez írhatunk scripteket is.

\subsubsection{Matlab}

A Matlab a MathWorks programcsomagja és programozási nyelve is egyben, egy nagyon elterjedt megoldás és számos helyen használják: numerikus számítások, robotika, adat elemzés, gépi tanulás, jel feldolgozás, kockázat elemzés, és irányító rendszerek fejlesztéséhez. Elsődlegesen mátrix müveletekre és numerikus számításokra készült, ezáltal nagyon jól kezeli a mátrixokat és vektorokat. Képes több szálon dolgozni és támogatja a procedurális és objektum orientált programozási paradigmákat is.

\subsubsection{Python}

A Python egy nagyon magas szintü, platform független, általános programozási nyelv. Nagyon nagy előnye a könnyü tanulhatósága és olvasható szintaktikája, sokoldalúsága és bővíthetősége. Ezen tulajdonságai miatt rengeteg területen alkalmazzák. A NumPy, SimPy, SciPy és Matplotlib csomagokat használva hatékony alternatív eszközt nyújt a numerikus számításokhoz.

\subsubsection{GNU Octave}

A GNU Octave egy magas szintủ nyelv, mely elsődlegesen numerikus számításokhoz lett kitalálva, egy kényelmes parancssoros felületet biztosítva, lineáris és nem lineáris problémák numerikus megoldásához és más numerikus kísérletekhez, egy olyan nyelvet használva, amely nagymértékben kompatibilis a Matlab-bal. Az Octave kiterjedt eszközkészletet nyújt a leggyakoribb numerikus problémák megoldására, könnyedén testre szabható és kiterjeszthető a felhasználó által írt metódusokkal, melyek íródhatnak az Octave saját nyelvén, vagy dinamikusan betölthető modulokban, melyek más nyelven íródtak, mint $\mathrm{C}$ vagy $\mathrm{C}++$ esetleg Fortran, vagy valami egyéb nyelven.

\section{Használt környezet és a mérések menete}

A méréseket az alábbi környezetben végeztem el:

\subsection{Szoftveres környezet}

Használt csomagok:

- GNU Octave 5.2.0

- Matlab R2020a (Trial)

- Python 3.7.4

- Numpy 1.16.5

- SciPy 1.3.1 
- használt fejlesztő környezetek:

- PyCharm Professional 2019.2

- Matlab saját felhasználói felülete (Matlab GUI)

- Octave saját felhasználói felülete (Octave GUI)

Operációs rendszer: Windows 10 Pro v.2004 64 bit

\subsection{Hardveres környezet}

Használt hardver:

- Processzor: Intel i7 7700HQ

- Memória: 8GB

\subsection{Mérések menete}

A méréseket az alábbi módon végeztem el:

- Minden teszt elött általánosan leírom az adott problémát.

- Csak az adott müvelet elvégzésének idejét mértem le.

- Az adott programot 200 alkalommal futtattam le.

- A kapott eredmények átlagát vizsgálom és tüntetem fel a cikkben.

- Az adatok melyeken a műveleteket végeztem véletlenszerúen generáltak, ahol nem ott fel van tüntetve, a generálás ideje nincs benne a művelet elvégzéséhez szükséges mért időben.

- A generált véletlenszerú adatok lebegöpontos számok, ahol nem ott feltüntetem azt, hogy nem.

- Ahol egyéb kitételek is vannak az adatok ezeknek megfelelően lettek le generálva, szintén véletlenszerüen (pl.: mátrix pozitív definitása).

- A mérések esetén igyekeztem a nyelv vagy programcsomag által nyújtott lehetőségeket használni, tehát a nyelv által nyújtott metódusokat mértem le, ahol egy algoritmus általam elkészített implementációja szerepel, azt fel fogom tüntetni.

\section{Egyszerü mátrix múveletek}

Elöször is nézzük meg, mi az a mátrix. A mátrix a matematikában valamilyen mennyiségek téglalap alakú elrendezésben. Ezek a mennyiségek lehetnek egyszerủ számok, de akár függvények is, vagy esetleg más mátrixok is. Mátrixokkal elvégezhető müveletek: transzponálás, mátrixok összeadása, mátrix szorzás, skalárral való szorzás. Az első két tesztben a mátrixszorzást és -összeadást fogom megvizsgálni. Az (1) képletben egy példa mátrix látható.

$$
A=\left[\begin{array}{ccc}
a_{11} & \cdots & a_{1 m} \\
\vdots & \ddots & \vdots \\
a_{n 1} & \cdots & a_{n m}
\end{array}\right]
$$

\subsection{Mátrix összeadás}

Mátrixok összeadása során (2) a két mátrix megfelelő indexủ elemeit adjuk össze. Ezáltal a csak is két azonos dimenziójú mátrix adható össze. 


$$
A_{n m}+B_{n m}=C_{n m}=\left[\begin{array}{cccccccc}
a_{11} & + & b_{11} & \cdots & \cdots & a_{1 m} & + & b_{1 m} \\
& \vdots & & & & & \vdots & \\
& \vdots & & & \ddots & & \vdots & \\
& \vdots & & & & & \vdots & \\
a_{n 1} & + & b_{n 1} & \cdots & \cdots & a_{n m} & + & b_{n m}
\end{array}\right]
$$

Az első tesztben nagy méretủ mátrixok összeadásának a sebességét mértem. A mátrixok méretei az alábbiak voltak $1024 \times 1024,2048 \times 2048,4096 \times 4096,8192 \times 8192$. Az eredményeket az alábbi táblázat foglalja össze:

1. táblázat. Mátrixok összeadásának ideje (másodperc)

\begin{tabular}{|c|c|c|c|c|}
\hline Mátrix mérete & $\mathbf{1 0 2 4} \times \mathbf{1 0 2 4}$ & $\mathbf{2 0 4 8} \times \mathbf{2 0 4 8}$ & $\mathbf{4 0 9 6} \times \mathbf{4 0 9 6}$ & $\mathbf{8 1 9 2} \times \mathbf{8 1 9 2}$ \\
\hline Python & 0,003018 & 0,01045 & 0,03987 & 0,17591 \\
\hline Matlab & 0,003108 & 0,01064 & 0,04156 & 0,15829 \\
\hline Octave & 0,003651 & 0,01357 & 0,05235 & 0,21306 \\
\hline
\end{tabular}

A táblázatból látható, hogy mind a három nyelv közel azonos idővel végzi el a müveleteket, viszont ahogy növeljük a méretet, a Matlab és a Python kezd gyorsabb lenni, mint az Octave. A Python és az Matlab nagyon hasonló időket produkálnak.

\subsection{Mátrix szorzás}

Két mátrixok akkor szorozhatunk össze, ha a bal oldali mátrix oszlopainak a száma megegyezik a jobb oldali mátrix sorainak a számával, és a kapott mátrixunknak annyi sora lesz, mint a szorzás bal oldalán álló mátrixnak, és annyi oszlopa, amennyi a szorzás jobb oldalán lévő mátrixnak. A (3) képletben a mátrix szorzás általános alakja látható.

$$
A_{m n} * B_{n k}=C_{m k}
$$

Az egyes indexeken lévő értékeket pedig a következő módon számolhatjuk ki, az eredmény mátrix egy pontjában található érték számolása:

$$
C_{i j}=\sum_{p=1}^{n} A_{i p} * B_{p j}\left(i \in 1,2,3 \ldots m, \quad j \in 1,2,3 \ldots k, \quad A \in M_{m n} \quad B \in M_{n k} \quad C \in M_{m k}\right)
$$

A következő mérésben a feladat hasonló volt az előzőhöz: a mátrixok méretei megegyeznek, az eltérés csupán annyi, hogy nem összeadjuk, hanem összeszorozzuk a mátrixokat, mivel a mátrixok négyzetes alakúak így a szorzás feltételének eleget tesznek.

A Python lett ebben a tesztben a leggyorsabb, de csak egy hajszálnyival maradt le a Matlab tőle. Az Octave most is lassabb volt, mint a másik két társa. A Python a végén már jelentősnek nevezhetö, majdnem 1 másodperces előnye a Matlab-hoz és több, mint 2 másodperces előnye az Octave-hoz viszonyítva, valamint a tendenciát figyelembe véve, azt jelentheti, hogy a méretet tovább növelve a Python előnye tovább nőhet és egyértelmü előnyt jelenthet a másik két vizsgált nyelvhez képest. 
Numerikus számítások hatékonyságának vizsgálata

2. táblázat. Mátrixok összeszorzásának ideje (másodperc)

\begin{tabular}{|c|c|c|c|c|}
\hline Mátrix mérete & $\mathbf{1 0 2 4} \times \mathbf{1 0 2 4}$ & $\mathbf{2 0 4 8} \times \mathbf{2 0 4 8}$ & $\mathbf{4 0 9 6} \times \mathbf{4 0 9 6}$ & $\mathbf{8 1 9 2} \times \mathbf{8 1 9 2}$ \\
\hline Python & 0,0271955 & 0,138602 & 1,276361 & 9,0625243 \\
\hline Matlab & 0,0244138 & 0,147037 & 1,312633 & 10,535636 \\
\hline Octave & 0,0238087 & 0,154890 & 1,553110 & 11,695740 \\
\hline
\end{tabular}

\subsection{LU felbontás}

Egy mátrix LU felbontása a következőt jelenti: a mátrixot felbontjuk, úgy egy alsó (Lower) és felső (Upper) háromszögmátrixra, úgy, hogy ezek szorzatának eredménye az eredeti mátrixunk legyen. (5) Az LU felbontás általános alakja és $3 \times 3$-as példa az LU felbontásra.

$$
\begin{gathered}
{\left[\begin{array}{lll}
a_{11} & a_{12} & a_{13} \\
a_{21} & a_{22} & a_{23} \\
a_{31} & a_{32} & a_{33}
\end{array}\right]=} \\
A=L U \\
A=\left[\begin{array}{ccc}
l_{11} & 0 & 0 \\
l_{21} & l_{22} & 0 \\
l_{31} & l_{32} & l_{33}
\end{array}\right] \times\left[\begin{array}{ccc}
u_{11} & u_{12} & u_{13} \\
0 & u_{22} & u_{23} \\
0 & 0 & u_{33}
\end{array}\right] \\
A=L
\end{gathered}
$$

3. táblázat. LU felbontás ideje (másodperc)

\begin{tabular}{|c|c|c|c|c|}
\hline Mátrix mérete & $\mathbf{1 0 2 4} \times \mathbf{1 0 2 4}$ & $\mathbf{2 0 4 8} \times \mathbf{2 0 4 8}$ & $\mathbf{4 0 9 6} \times \mathbf{4 0 9 6}$ & $\mathbf{8 1 9 2} \times \mathbf{8 1 9 2}$ \\
\hline Python & 0,032241 & 0,167806 & 0,817745 & 5,221102 \\
\hline Matlab & 0,020194 & 0,100511 & 0,507782 & 4,512361 \\
\hline Octave & 0,050461 & 0,244357 & 1,313597 & 8,335829 \\
\hline
\end{tabular}

Ez a teszt már kicsit látványosabb különbségeket produkált. Az LU-felbontásos tesztet a Matlab nyerte 0,7 másodperces előnnyel a legnagyobb mátrix esetében, a Python előtt. Ezúttal az Octave jelentősen lassabb volt mind a két társánál.

\subsection{Cholesky-felbontás}

Cholesky-felbontás esetén a mátrixot felbontjuk egy olyan alsó (vagy felsö) háromszög mátrixra, melyet, ha összeszorzunk az adjungáltjával, akkor annak a szorzásnak az eredménye maga a mátrix, amelyből kiindultunk. A Cholesky-felbontás csakis szimmetrikus, pozitív-definit mátrixok esetén használható. (6) A lineáris egyenletrendszer általános alakja.

$$
A=L L^{*}
$$

A mátrixok a tesztnél szimmetrikus és pozitív definit mátrixok voltak. A Matlab és az Octave a felső míg a Python által használt NumPy csomagban található metódus az alsó háromszög mátrixot számolta ki, de azt feltételeztem, hogy ez a sebességre nem lehet számottevő hatással. Ebben a tesztben is a Matlab 
volt a leggyorsabb, amit szintén a Python követett, hasonlóan az előző LU felbontásos tesztesetnél. Az Octave itt is a leglassabb volt.

4. táblázat. Cholesky felbontás ideje (másodperc)

\begin{tabular}{|c|c|c|c|c|}
\hline Mátrix mérete & $\mathbf{1 0 2 4} \times \mathbf{1 0 2 4}$ & $\mathbf{2 0 4 8} \times \mathbf{2 0 4 8}$ & $\mathbf{4 0 9 6} \times \mathbf{4 0 9 6}$ & $\mathbf{8 1 9 2} \times \mathbf{8 1 9 2}$ \\
\hline Python & 0,028166 & 0,190326 & 0,725186 & 3,444141 \\
\hline Matlab & 0,005782 & 0,036046 & 0,283129 & 1,851955 \\
\hline Octave & 0,019151 & 0,086200 & 0,572526 & 5,492876 \\
\hline
\end{tabular}

\subsection{Lineáris egyenletrendszerek megoldása}

A lineáris egyenletrendszer olyan többismeretlenes egyenletrendszer, ahol minden ismeretlen első hatványon szerepel. Általános alakja:

$$
A x=b,
$$

ahol $A$ az együttható mátrix $b$ az eredmény vektor és $x$ az ismeretlenek vektora. A feladatunk, hogy az $x_{i}(i \in 1,2,3 \ldots \mathrm{n})$ értékeket meghatározzuk.

A következő teszt eltérő a többitől, mivel ezt a tesztet lebegőpontos számok helyett egész számokkal végeztem. Különbség még a mátrixok méretében is van, ugyanis óriási futási időket tapasztaltam a Python esetében, amire a következő tesztben bővebben is ki fogok térni. A Python egész számokat lassan generál, ezért lecsökkentettem az együttható mátrixok méretét rendre $512 \times 512,768 \times 768,1024 \times$ $1024,1280 \times 1280$ elemüre.

5. táblázat. Lineáris egyenletrendszerek megoldása (másodperc)

\begin{tabular}{|c|c|c|c|c|}
\hline Mátrix mérete & $\mathbf{5 1 2} \times \mathbf{5 1 2}$ & $\mathbf{7 6 8} \times \mathbf{7 6 8}$ & $\mathbf{1 0 2 4} \times \mathbf{1 0 2 4}$ & $\mathbf{1 2 8 0} \times \mathbf{1 2 8 0}$ \\
\hline Python & 0,002711 & 0,006479 & 0,019265 & 0,029832 \\
\hline Matlab & 0,005896 & 0,016951 & 0,049608 & 0,081372 \\
\hline Octave & 0,017313 & 0,043528 & 0,090767 & 0,148583 \\
\hline
\end{tabular}

Maga az egyenletrendszerek megoldása nagyon gyorsan végbe ment minden esetben, a leggyorsabban a Python oldotta meg őt a Matlab követi végül jön az Octave. A képet viszont árnyalja, hogy mégis a Python dolgozott a legtovább a lassú integer generálásának köszönhetően.

\subsection{Randomszám-generálás}

Az előző tesztben tapasztaltak miatt, gondoltam mégis jó lenne ebből a szempontból is összevetni a nyelveket, itt külön táblázatba fogom szedni a Pythont, hiszen a másik két nyelv, majdhogynem külön ligában játszik egész számok esetén. A tesztben a lineáris egyenletrendszereknél bevezetett méreteket fogom használni. Kezdjük is el a Python eredményeivel. A tesztnél nem csak az egyszerű random 
számokból álló mátrixot generáltam, hanem pozitív definit mátrixokat, úgyhogy a mért időben még benne van még 4 másik művelet is.

6. táblázat. Randomszám-generálás: Python (másodperc)

\begin{tabular}{|c|c|c|c|c|}
\hline Mátrix mérete & $\mathbf{5 1 2} \times \mathbf{5 1 2}$ & $\mathbf{7 6 8} \times \mathbf{7 6 8}$ & $\mathbf{1 0 2 4} \times \mathbf{1 0 2 4}$ & $\mathbf{1 2 8 0} \times \mathbf{1 2 8 0}$ \\
\hline Python (egész) & 0,218987 & 0,723971 & 1,737466 & 3,37302 \\
\hline $\begin{array}{c}\text { Python } \\
\text { (lebegópontos) }\end{array}$ & 0,002108 & 0,005148 & 0,008674 & 0,01289 \\
\hline
\end{tabular}

Látható, hogy a lebegőpontos szám generálási idejének többszöröse az egész generálási ideje és a méret kis mértékü növelése is nagyon meg tudja növelni az időket. Ennek az okának meghatározásához bele kell nézni a generáló metódus forrás kódjába és plusz egy kis utána olvasás után azt szürtem le, hogy a metódus sok ellenőrzést végez annak érdekében, hogy minden esetben hiba nélkül le tudjon futni, de ennek a cikknek nem feladata a pontos okot kideríteni, úgyhogy a továbbiakban nem foglalkozomk a problémával. Menjünk is tovább a Matlab és az Octave eredményeivel.

7. táblázat. Random szám generálás: Matlab és Octave (másodperc)

\begin{tabular}{|c|c|c|c|c|}
\hline Mátrix mérete & $\mathbf{5 1 2} \times \mathbf{5 1 2}$ & $\mathbf{7 6 8} \times \mathbf{7 6 8}$ & $\mathbf{1 0 2 4} \times \mathbf{1 0 2 4}$ & $\mathbf{1 2 8 0} \times \mathbf{1 2 8 0}$ \\
\hline Matlab (egész) & 0,005340 & 0,012314 & 0,021890 & 0,032335 \\
\hline $\begin{array}{c}\text { Matlab } \\
\text { (lebegőpontos) }\end{array}$ & 0,005007 & 0,010509 & 0,019010 & 0,028215 \\
\hline Octave (egész) & 0,014099 & 0,032247 & 0,057917 & 0,088373 \\
\hline $\begin{array}{c}\text { Octave } \\
\text { (lebegőpontos) }\end{array}$ & 0,006984 & 0,016511 & 0,030821 & 0,045790 \\
\hline
\end{tabular}

Mint látható, a Matlabnak és az Octave-nak nem okoz gondot a random egész szám generálás, bár számomra érdekes módon a lebegőpontos számok generálása itt is gyorsabb. Meg kell jegyezni, a Matlab itt is gyorsabb az Octave-nál.

\subsection{Sajátérték, sajátvektor}

A mátrixok sajátértékéhez és sajátvektorához szükségünk lehet a komplex számok halmazára is. Egy ilyen komplex számokból álló mátrixot a valós számokból állóhoz hasonlóan $\mathbb{C}^{m \times n}-$ el jelöljük $\left(R^{m x n} \subset C^{m x n}\right)$. Nézzük elöször a sajátvektor és a sajátérték definícióját!

Legyen $A \in \mathbb{C}^{n x n}$ tetszőleges mátrix. $A, \lambda \in \mathbb{C}$ számot az $A$ mátrix sajátértékének és az $x \in$ $\mathbb{C}^{n}(x \neq 0)$ vektort pedig $\lambda$ sajátértékhez tartozó sajátvektornak nevezzük, ha

$$
A x=\lambda x
$$

Fontos, hogy egy mátrix sajátértékeinek összeségét a mátrix spektrumának nevezzük és a spektrumból a mátrix fontos tulajdonságait lehet kiolvasni például az alábbiakat.

- Egy négyzetes mátrix akkor és csak akkor nemszinguláris, ha egyik sajátértéke sem nulla.

- Egy mátrix akkor és csak akkor pozitív definit, ha minden sajátértéke pozitív. 
A sajátértékeket úgy kaphatjuk meg, ha megoldjuk a karakterisztikus egyenletet, amely a következő:

$$
\phi(\lambda)=\operatorname{det}(A-\lambda i)=0
$$

A mátrixok mérete ebben a teszteb 512 x 512, 1024 x 1024, 1536 x 1536, 2048 x 2048.

8. táblázat. Sajátérték és sajátvektor számolás (másodperc)

\begin{tabular}{|c|c|c|c|c|}
\hline Mátrix mérete & $\mathbf{5 1 2} \times \mathbf{5 1 2}$ & $\mathbf{1 0 2 4} \times \mathbf{1 0 2}$ & $\mathbf{1 5 3 6} \times \mathbf{1 5 3 6}$ & $\mathbf{2 0 4 8} \times \mathbf{2 0 4 8}$ \\
\hline Python & 0,242369 & 0,969306 & 2,606619 & 5,762008 \\
\hline Matlab & 0,232779 & 0,946277 & 2,553774 & 5,725959 \\
\hline Octave & 0,554634 & 1,886882 & 4,510491 & 9,013209 \\
\hline
\end{tabular}

A Matlab ekkor egy hangyányival gyorsabb csak, mint a Python, míg az Octave jelentősebb lassabb volt tölük.

\subsection{Interpoláció}

Az interpoláció egy közelítő módszer a matematikában, mellyel egy függvény nem ismert értékeit határozzuk meg. A lényege matematikailag az, hogy adott az $f(x)$ függvény és adottak az $x_{1} \ldots x_{n}$ pontokban felvett értékei az $\left[a=x_{1}, b=x_{n}\right]$ intervallumban és magát az $f(x)$ függvényt szeretnénk közelíteni egy könnyen számolható $h(x)$ függvénnyel, melyre fennáll, hogy $f\left(x_{i}\right)=h\left(x_{i}\right)$.

A mostani tesztben az alábbi függvényt interpoláltam a [0,30] intervallumban: $\left(x^{3}\right) / 4$ és az interpolációkban meghatározandó pontok száma 100 000, 200 000, 300000 és 400000 darab pont a már fent említett intervallumon. Az adott nyelvek a saját interpolációs eljárásukat használták, 30 darab függvényérték volt megadva az intervallumban (0-tól 30-ig az egész számokon felvett függvény érték).

9. táblázat. Interpoláció saját eljárással (másodperc)

\begin{tabular}{|c|c|c|c|c|}
\hline Pontok száma & $\mathbf{1 0 0 0 0 0}$ & $\mathbf{2 0 0} 000$ & $\mathbf{3 0 0} 000$ & $\mathbf{4 0 0 0 0 0}$ \\
\hline Python & 0,001299 & 0,002884 & 0,004422 & 0,006021 \\
\hline Matlab & 0,000161 & 0,000060 & 0,000044 & 0,000042 \\
\hline Octave & 0,002694 & 0,002028 & 0,001994 & 0,001987 \\
\hline
\end{tabular}

Az eredmény kissé meglepő a Matlab és az Octave gyorsult a pontok számának növelésével, míg a Python ahogy elvárható volt lassult, a Matlab volt magasan a leggyorsabb, de a Python és az Octave is nagyon gyors volt.

\subsection{Spline interpoláció}

A Spline esetén szintén adott az intervallum, $f(x)$ függvény és az $y_{i}$ függvény értékeink és a feladat az, hogy megkeressük azt az $S(x)$ függvényt, mely teljesíti az alábbi feltételeket: 

(1.) $S(x)=S_{i}(x)$,
$x \in\left[x_{i}, x_{i+1}\right]$,
(2.) $S\left(x_{i}\right)=y_{i}$,
$(i=1, \ldots, n)$,
(3.) $S_{i}\left(x_{i+1}\right)=S_{i+1}\left(x_{i+1}\right)$,
$(i=1, \ldots, n-2)$

Az első feltétel megfogalmazza, hogy szakaszokból áll a függvényünk, a második megmondja, hogy valóban interpoláló függvény az $S(x)$ függvényünk, és a harmadikkal a folytonosság van definiálva az az $[a, b]$ intervallumon.

10. táblázat. Spline interpoláció (másodperc)

\begin{tabular}{|c|c|c|c|c|}
\hline Pontok száma & $\mathbf{1 0 0 0 0 0}$ & $\mathbf{2 0 0 0 0 0}$ & $\mathbf{3 0 0 0 0 0}$ & $\mathbf{4 0 0} \mathbf{0 0 0}$ \\
\hline Python: & 0,004153 & 0,007814 & 0,011618 & 0,015247 \\
\hline Matlab & 0,000145 & 0,000047 & 0,000039 & 0,000038 \\
\hline Octave & 0,003727 & 0,002801 & 0,002788 & 0,002783 \\
\hline
\end{tabular}

A tesztben a Matlab volt ismét a leggyorsabb, de szintén nagyon gyors volt az összes környezet. A Python és az Octave lassultak a teszt során az előző méréshez képest, míg a Matlab gyorsult.

\subsection{Numerikus deriválás}

A numerikus deriválás alapfeladata a következö, adott az $f: D(\subseteq \mathbb{R}) \rightarrow \mathbb{R}$ függvény, amely analitikusan ismeretlen vagy nehezen számolható, esetleg csak diszkrét pontokban ismert, és az $f$ függvényünk deriváltját szeretnénk közelíteni adott pontokban.

Nekifuthatunk úgy a feladatnak, hogy az $f$ függvényünkhöz készítünk egy interpolációt és az interpolációnk k-adik deriváltja fogja közelíteni az $f$ függvényünk k-adik deriváltjához.

Ha $f \in C^{2}[a, b]$, akkor felírhatjuk rá a másodfokú Taylor-polinomot, amelyből kifejezhető az alábbi összefüggés, (11) numerikus első derivált:

$$
f^{\prime}(x) \approx \frac{f(x+h)-f(x)}{h},
$$

a képlet hibája $O(h)$.

A harmadfokú Taylor-polinommal még pontosabb közelítést kaphatunk, (12) numerikus első derivált harmadfokú Taylor-polinomból kifejezve:

$$
f^{\prime}(x) \approx \frac{f(x+h)-f(x-h)}{2 h} .
$$

A másodfokú deriváltra az alábbi két összefüggést alkalmazhatjuk: (13) numerikus másodfokú derivált, (14) centrális differencia formula:

$$
f^{\prime(x)} \approx \frac{f(x)-2 f(x+h)+f(x+2 h)}{h^{2}},
$$




$$
f^{\prime \prime}(x) \approx \frac{f(x+h)-2 f(x)+f(x-h)}{h^{2}} .
$$

Mindkét képlet hibája $O\left(h^{2}\right)$. A tesztben az alábbi függvények deriváltjait számoltattam ki a fenti módszerek általam elkészített implementációjával:

$$
\begin{aligned}
& -f(x)=\cos \left(x^{3}\right)-1 \\
& -g(x)=x^{2}+x^{3}+3 \\
& -h(x)=\sin (x)^{2}+3 x+5+\tan (x+2) \\
& -j(x)=\sin \left(x^{20}+x^{30}+3\right)^{4}+31 x+6 x^{12}
\end{aligned}
$$

11. táblázat. Numerikus deriválás (másodperc)

\begin{tabular}{|c|c|c|c|c|}
\hline Függvényt & $f(x)$ & $g(x)$ & $h(x)$ & $j(x)$ \\
\hline $\begin{array}{c}\text { Python első } \\
\text { derivált }\end{array}$ & 0,001664 & 0,002764 & 0,003953 & 0,005021 \\
\hline $\begin{array}{c}\text { Python } \\
\text { második } \\
\text { derivált }\end{array}$ & 0,002276 & 0,003721 & 0,005686 & 0,007285 \\
\hline $\begin{array}{c}\text { Matlab első } \\
\text { derivált }\end{array}$ & 0,004235 & 0,003542 & 0,003343 & 0,004005 \\
\hline $\begin{array}{c}\text { Matlab } \\
\text { második } \\
\text { derivált }\end{array}$ & 0,004294 & 0,003545 & 0,003374 & 0,005346 \\
\hline $\begin{array}{c}\text { Octave első } \\
\text { derivált }\end{array}$ & 0,076524 & 0,057344 & 0,097503 & 0,064113 \\
\hline $\begin{array}{c}\text { Octave } \\
\text { második } \\
\text { derivált }\end{array}$ & 0,071820 & 0,056799 & 0,089114 & 0,079865 \\
\hline
\end{tabular}

A teszt eredménye a következő: a Matlab volt a leggyorsabb mind az első, mind a második derivált kiszámításánál, őt követi a Python és jön az Octave harmadikként.

\subsection{Numerikus integrálás}

Integrálás során a Newton-Leibnitz-formulából indulhatunk ki. Ha az adott $f$ függvényünk Reimannintegrálható $[a, b]$-n, és itt létezik primitív függvénye, akkor

$$
I=\int_{a}^{b} f(x) d x=F(b)-F(a) .
$$

Ez a módszer viszont csak akkor alkalmazható, ha $f$-nek létezik primitív függvénye, ha nincs, akkor viszont numerikus integrálást kell alkalmaznunk. Numerikus integrálás során az $f$ függvényt közelítjük egy $p$ interpolációs polinommal és ezáltal a határozott integrál értékét közelítjük, általános formában:

$$
I=\int_{a}^{b} f(x) w(x) d x \approx \int_{a}^{b} p(x) w(x) d x,
$$


ahol $w(x) \geq 0$ pedig egy tetszőleges súlyfüggvény.

Numerikus integrálást rengeteg algoritmussal le lehet írni, vannak egyszerübbek (például: trapéz-, téglalap formulák) és bonyolultabbak is. Ezek egy része visszavezethető a nyílt vagy zárt NewtonCotes-formulákra. A teszt során a numerikus deriválásnál megismert függvényeket $(f(x), g(x), h(x), j(x))$ fogom a $[0,100]$ - intervallumon integrálni az általam implementált összetett Simpson formula segítségével.

$$
\int_{a}^{b} f(x) d x \approx \sum_{i=0}^{n-1} \frac{x_{i+1}-x_{i}}{6}\left[f\left(x_{i}\right)+4 f\left(\frac{x_{i}+x_{i+1}}{2}\right)+f\left(x_{i+1}\right)\right]
$$

12. táblázat. Numerikus deriválás (másodperc)

\begin{tabular}{|c|c|c|c|c|}
\hline Függvény & $f(x)$ & $g(x)$ & $h(x)$ & $j(x)$ \\
\hline Python & 0,003258 & 0,004483 & 0,006469 & 0,007976 \\
\hline Matlab & 0,000710 & 0,000544 & 0,000290 & 0,002493 \\
\hline Octave & 0,074990 & 0,058867 & 0,093007 & 0,081972 \\
\hline
\end{tabular}

A Matlab volt a leggyorsabb, a Python nem sokkal követi, az Octave-nak sokszorosa kellett a Matlab vagy a Python idejének, egy-egy integrál kiszámításához.

\section{Konklúzió}

Összességében a tesztek eredménye az lett, hogy a legtöbb esetben a Matlab lett a leggyorsabb, amit a Python követ, míg az Octave csak a harmadik. Most szeretném összegezni a nyelvek előnyeit, hátrányait. Látszik, hogy a Matlab volt a leggyorsabb, ez kiegészül azzal, hogy a nyelv könnyen tanulható és sok mindent támogat, mint például a GPU-gyorsítást egyszerúen, amit nem használtam a teszteknél, de a segítségével még gyorsabb tudna lenni. Hátulütője a dolognak, hogy a programcsomag nem ingyenes. A Python és az Octave ingyenes, hiszen a Python egy általános magasszintű nyelv, ami nem pont ilyen célra lett kitalálva, de bizonyította már többször, hogy akár erre is használható. A GPU-gyorsítást ez is támogatja, bár igaz, korlátozásokkal. A Python mint nyelv a könnyebben tanulhatóak közé tartozik, de jelentősen eltér, így is a Matlab vagy akár más specifikusan ilyen célra tervezett nyelvektől. Az Octave volt a leglassabb, miért választaná ezt valaki? A válasz egyszerü, az Octave ingyenes és a Matlab nyelvét használja a kódok, melyek lefutnak a Matlab környezet alatt, nagy eséllyel lefutnak Octave alatt is. A tesztben a Matlab és az Octave kódok nagyrésze ugyanaz volt egy-két esetben volt csak minimális eltérés. Ellenben míg a Matlab-hoz kapunk támogatást az Octave esetén szükség esetén magunknak kell megtalálni a segítséget. A cikk konklúziója a következő, ha szükségünk van egy gyors könnyü nyelvre, amihez kapunk támogatást is és akár fizetnénk is érte, a Matlab egy jó választás. Abban az esetben viszont, ha ismerjük a Python-t, akkor a NumPy és SciPy csomagokkal nagyon jól használható ilyen célra is. Az Octave arra a legjobb, ha nem szeretnénk fizetni, vagy kisebb projekteket szeretnénk végre hajtani, vagy pedig olyan kódot szeretnénk írni, ami később kompatibilis a Matlabbal. 


\section{Irodalom}

[1] Ford, W.: Numerical linear algebra with applications: Using MATLAB, Academic Press, London, 2014.

[2] Walt, Stéfan van der, Colbert, S. C., Varoquaux, G.: The NumPy array: a structure for efficient numerical computation, Computing in Science \& Engineering 2011, 13(2): 22-30. https://doi.org/10.1109/MCSE.2011.37

[3] Hansen, J. S.: GNU Octave: Beginner's Guide: Become a proficient octave user by learning this high-level scientific numerical tool from the ground up, Packt Publishing Ltd., Birmingham, 2011.

[4] Shampine, L. F., Allen, R. C., Pruess, S.: Fundamentals of numerical computing, New York: Wiley, 1997.

[5] Davis, P. J., Rabinowitz, P.: Methods of numerical integration, Courier Corporation, North Chelmsford, 2007.

[6] Kincaid, D., Kincaid, D. R., Cheney, E. W.: Numerical analysis: mathematics of scientific computing, American Mathematical Soc., Rhode Island, 2009.

[7] Galántai, A.: Alkalmazott lineáris algebra, Miskolc: Miskolci Egyetemi Kiadó, 1996.

[8] Trefethen, L. N., Bau, III. D.: Numerical linear algebra, Siam, 1997. https://doi.org/10.1137/1.9780898719574

[9] Kahan, W.: Numerical linear algebra, Canadian Mathematical Bulletin 1966, 9(5): 757-801. https://doi.org/10.4153/CMB-1966-083-2

[10] Forrás kódok a cikkben szereplő mérésekhez: https://github.com/gyulaimark97/Source-code-forthe-article-about-numerical-problems

[11] Guedes, P. F. S., Nepomuceno E. G.: Some remarks on the performance of Matlab, Python and Octave in simulating dynamical systems, https://arxiv.org/pdf/1910.06117v1.pdf 2019. https://doi.org/10.17648/sbai-2019-111188 